\title{
One Case of Triphallia in the Marine Snail Echinolittorina peruviana (Caenogastropoda: Littorinidae)
}

\author{
Un Caso de Trifalia en el Caracol Marino Echinolittorina peruviana (Caenogastropoda: Littorinidae)
}

\author{
Viviana M. Castillo \& Donald I. Brown
}

\begin{abstract}
CASTILLO, V. M. \& BROWN, D. I. One case of Triphallia in the Marine Snail Echinolittorina peruviana (Caenogastropoda: Littorinidae). Int. J. Morphol., 30(3):791-796, 2012.

SUMMARY: Gonochoric representatives of Littorinidae have a reproductive system organized with transit organs that connects the testicle with a penis specialized for internal fertilization. However, malformations at this level can produce, like triphallia (presence of triple penis). This description corresponds to one case of triphallia found in Echinolittorina peruviana (Lamarck, 1822) inhabitant of the South Pacific coasts. The macro and microscopic analysis reveals that every penis is an independent appendix whose individual morphology is similar to that in normal individuals, characterized by a non pigmented conic penis associated with a mammilliform gland located at the base of the right ocular tentacle. The cervical sperm groove lined by a simple ciliated and secretory columnar epithelium, runs along the neck of the animal, is subdivided into the base of each penis forming the penile seminal groove in each of them, and ascends dorsally from the base to the tip. The other organs that make up the reproductive system have a normal organization (no duplication or triplets), and the testicle organized in acini contains all the cell types of the male germ line. Although the cause of this condition is still unknown, might be associated with genetic causes and not of environmental kind.
\end{abstract}

KEYWORDS: Mollusk; Reproduction; Reproductive system; Penial morphology; Malformation; Littorinidae

\section{INTRODUCTION}

In animals, the evolution of internal fertilization has been a reproductive strategy that involves the organization of a reproductive system adapted for this type of fertilization. However, during the embryonic development may occur congenital malformations; among these, a duplication of the penis called diphallia, and although it is not frequent, is mainly observed in mammals including humans (Sharma et al., 2000). Real and full diphalia type consists in the formation of two independent penises; and incomplete diphallia consists in a bifurcated penis (Loynachan et al., 2006). However, the exact cause of such pathology is still unknown.

In molluscs the only reported case of diphallia corresponds to isolated females affected by imposex (Meirelles et al., 2007; Cardoso et al., 2008).

Echinolittorina peruviana, gonochoric representative of Littorinidae, presents a male reproductive system with transit organs connecting the testicle with a penis to transfer spermatozoa during copulation (Castillo \& Brown, 2008). The penis is conical and not pigmented, of wide base and sharp apex, is located at the base of the right ocular tentacle.
It is coated by a simple columnar pseudostratified epithelium with ciliated and secretory cells; and a central body of circular, longitudinal and radial to oblique muscle fibers associated with connective tissue, leaving haemolymphatic lacunae between them. As specialization of the epidermis, dorsally runs a sperm groove coated by a simple ciliated and secretory columnar epithelium. Towards anterior and adjacent to the base of the penis, presents a penile gland consisting of a mammilliform and a discoid region with a follicular organization (Castillo \& Brown).

In this paper we describe a case in Echinolittorina peruviana where a male presents a triple penis, phenomenon that we have termed "triphallia".

\section{MATERIAL AND METHOD}

Echinolittorina peruviana specimens were collected from the intertidal rocky zone at Carvallo beach $\left(33^{\circ} 1^{\prime}\right.$, , 
$71^{\circ} 38^{\prime}$ W) near Valparaíso, Chile. A total of 74 mature adult individuals were collected randomly. The size of the animals ranged from $7.45-14.20 \mathrm{~mm}$ in length and $5.60-12.70 \mathrm{~mm}$ wide (peristomal diameter). Sexual dimorphism was determined using two criteria: (1) absence or presence of penis and (2) gonad coloration, corresponding pink for females and orange for the males; (compare Fig. 1A and 1B). Collected specimens were measured, sexed, weighed and processed for macroscopic and histological analysis in the laboratory.

Macroscopic and histological analysis. The animals were dissected and anesthetized during 30 minutes at $4^{\circ} \mathrm{C}$, in a $1: 1$ solution of sea water and $7.5 \%$ aqueous $\mathrm{Cl} 2 \mathrm{Mg}$ (Pantín, 1967), once narcotised they were photographed, and subsequently fixed 24 hours in strong aqueous Bouin's solution. After fixation, they were rinsed in 70\% ethanol, dehydrated in a series of ascending concentrations of ethanol, cleared in butanol, embedded and included in Paraplast Plus (Gabe, 1968). Serial histological sections of $5 \mu \mathrm{m}$ thick, were mounted every $75 \mu \mathrm{m}$ on slides. The preparations were deparaffinized in xylenes, hydrated in a series of descending concentrations of ethanol until distilled water and stained with a trichrome method for topographic staining (Valderrama et al., 2004). After dehydration in $95 \%$ ethanol and clearing in xylenes, the slides were coverslipped using Entellan (Merck Chemicals, Germany) as mounting media. Histological preparations were analysed and the images were taken using a Leitz-Leica model DMRBE light microscope (Wetzlar, Germany) equipped with a Leica DFC290 digital camera, to characterize the reproductive system compromised in the triphallia abnormality.

\section{RESULTS}

Sexual proportion in the collected animals was close to 1: 1 (39 males; 35 females). They were not cases of imposex and only one male presented triphallia (presence of triple penis) (Fig. 1D), corresponding to the case reported in this paper. Penile morphology in this specimen was similar to the normal one, characterized by a conical and not pigmented penis, associated to a gland with a mammilliform and discoidal region (Fig. 1C). The location of the triple penis is at the base of the right ocular tentacle (Figs. 1D-E), as in normal males (Fig. 1B). The spermatic cervical groove that runs along the neck of the animal is subdivided into the base of each penis forming the penile seminal groove, and ascends dorsally from the base to the distal end of each penis (Fig. 1F). At the histologic level, it is observed that every penis is an independent appendix (Fig. 2A) with the corresponding mammilliform gland and over it, the more basal discoidal portion, mostly stained with aniline blue (Fig. 2B). The histological organization of every penis is similar (Figs. 2C-E): a characteristic organization with muscular fibers sharing with connective tissue, leaving spaces that corresponds to haemolymphatic lacunae; and a pseudostratified columnar epithelium as external lining. On its dorsal side runs a penile seminal groove which is lined with a simple ciliated and secretory columnar epithelium (Figs. 2C-E). The nuclei of epithelial cells of oval shape are mostly displaced towards the apical cytoplasm (Figs. 2C-E).

Histological analysis of other organs of the reproductive system of this animal are not triplicate and reveals that the prostate gland, seminal vesicle and gonad possess a normal organization (Figs. 2F-G). The seminal vesicle presents a large number of euspermatozoa and paraspermatozoa (Fig. 2F) in its lumen. The gonad organized in acini presents all the representative of early and advanced germline cells (Fig. 2G).

\section{DISCUSSION}

During embryonic development of gonochoric species, like mammals and some mollusks such as $E$. peruviana; somatic cells interact with germ cells and occurs a series of stimuli that triggers a cascade of genes and proteins, leading to the formation of organs and systems related to reproduction. However, disruptions in these interactions can lead to the production of congenital malformations in the individual in gestation.

Our observations indicate that this case corresponds to true and complete triphallia, because every penis shapes an independent appendix and not a genital tri-dissection of the organ. In mammals including humans, the clinical condition called diphallia, consists of the duplication of the penis and is considered an infrequent congenital malformation in the population (Sharma et al.). This condition may be accompanied by other duplicate organs, either, can correspond to isolated duplication which are observed mainly in the urogenital tract (Dardanelli et al., 2005), as it is the case we inform in this work. Penile morphology of each penis in this animal preserves the normal characteristics of shape and coloration, and also retains the normal characteristics of histological organization previously described for this species (Castillo \& Brown) which may indicate that the functionality would not be compromised in the triple penis. On the other hand, the histological analysis reveals that there are no duplicate or triplicate structures in other structures of the reproductive system. In addition, the testis where normal development of 

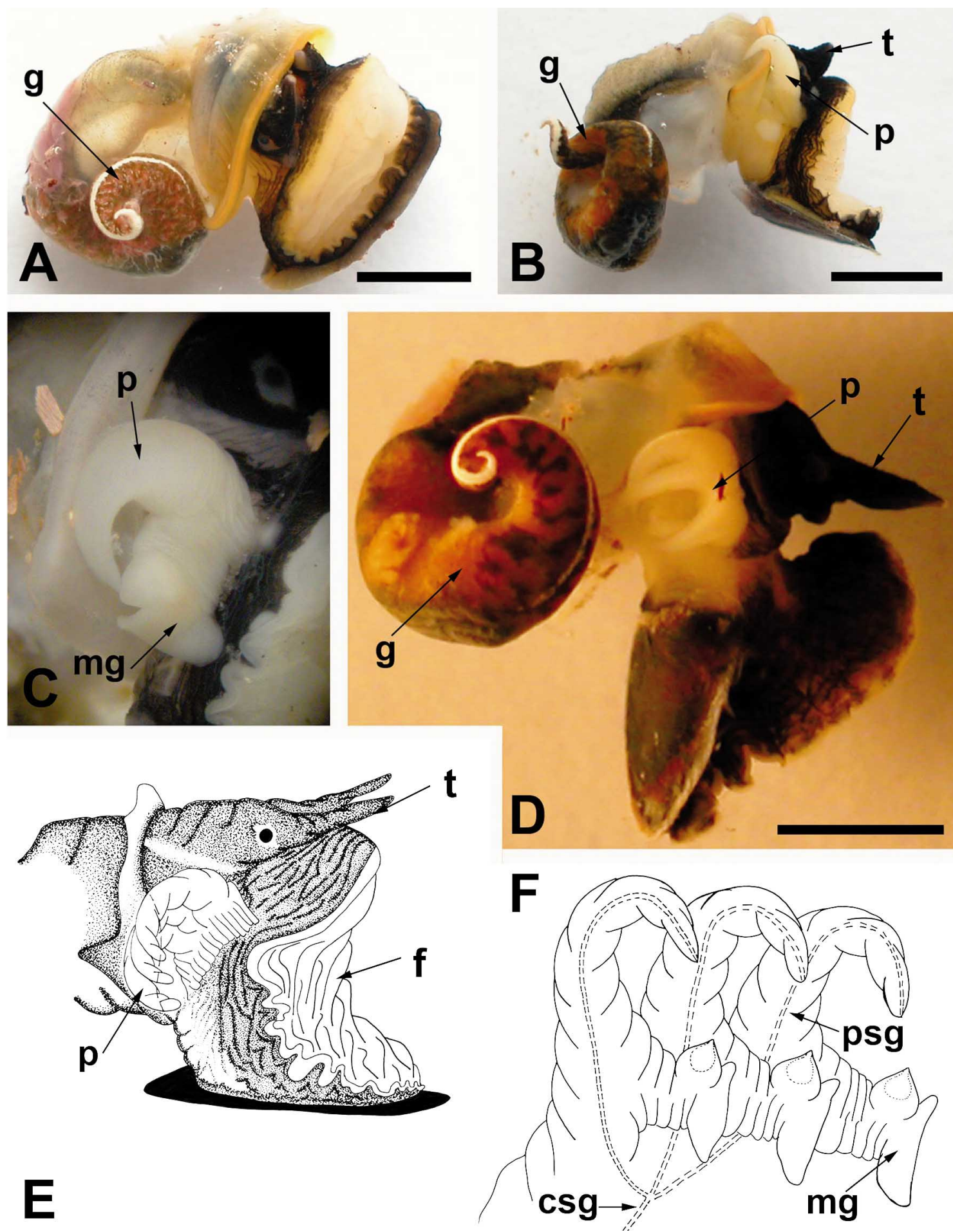

Fig. 1. External macroscopic view of Echinolittorina peruviana soft body after removing the shell. Photographs (A-D) and drawings (E-F) from the right lateral side showing details of the reproductive system. A. Female gonad. B. Normal male genitalia and gonad. C. Normal penile morphology. D. Abnormal penile morphology; male with triple penis (triphallia). E. Schematic drawing of the triple penile morphology (not to scale); mammilliform glands had been omitted in the scheme for a better understanding of penile position. F. Schematic drawing of the triple penile morphology (not to scale); detail of the cervical seminal groove and penile seminal groove branching. KEY: csg - cervical seminal groove; $\mathrm{f}$ - foot; $\mathrm{g}$ - gonad; $\mathrm{mg}$ - mammilliform gland; $\mathrm{p}$ - penis; psg - penile seminal groove; $\mathrm{t}$ - tentacle. Scale bars: A, B and D = $3 \mathrm{~mm}$. 

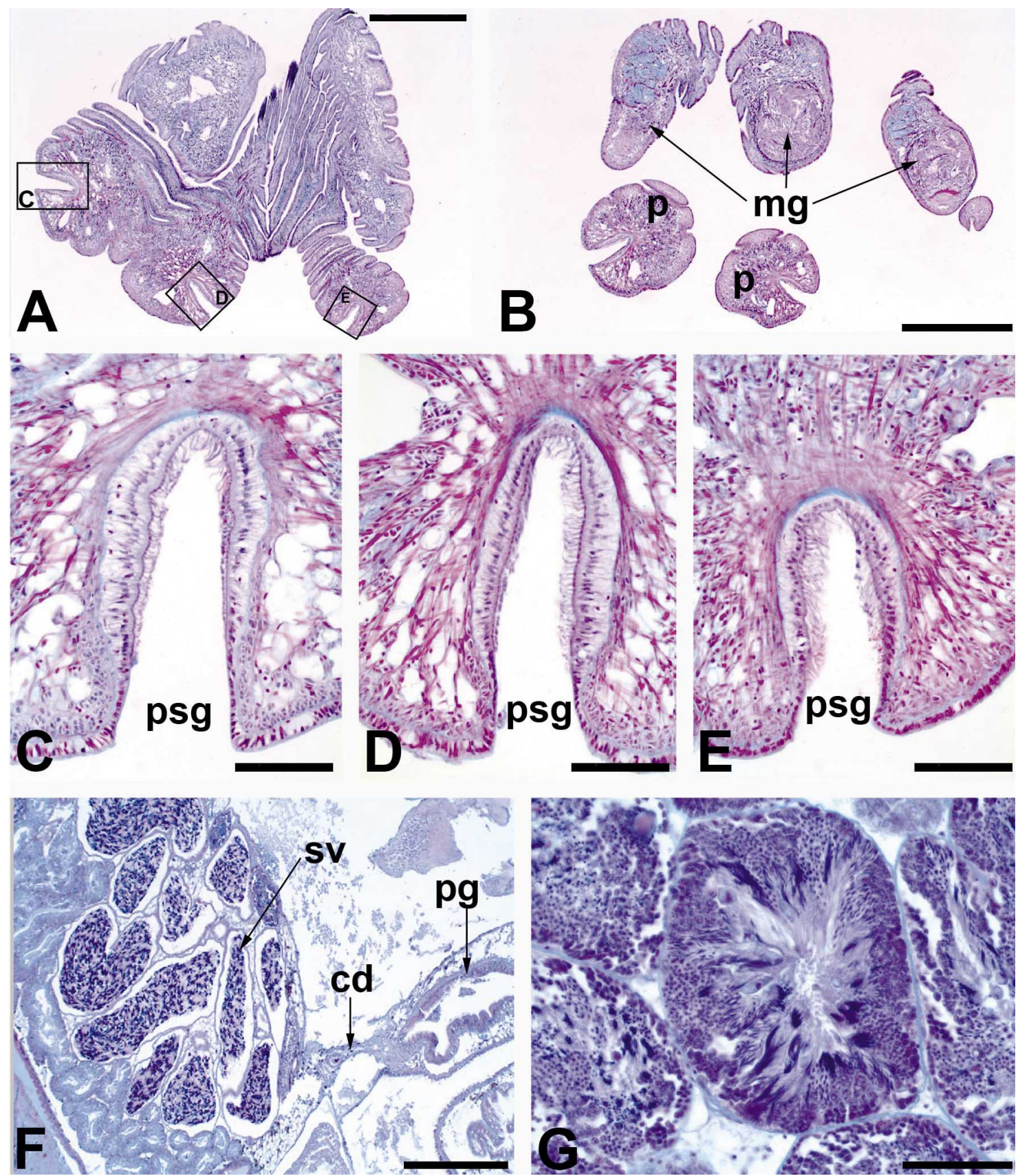

Fig. 2. Microphotographs of histological sections of the reproductive system from the Echinolittorina peruviana triple penis male. A. Cross section through the triple penis. B. Cross section of the penis and the mammilliform glands. C, D and E, Inserts in A: Magnifications of cross section from each penis. F. Histological organization of the prostate gland, connection duct and the seminal vesicle. G. Gonadic acinus. KEY: cd - connection duct; mg - mammilliform glands; p - penis; pg - prostate gland; psg - penile seminal groove; sv - seminal vesicle. Scale bars: A, B and $\mathrm{F}=400 \mu \mathrm{m} ; \mathrm{C}, \mathrm{D}, \mathrm{E}$ and $\mathrm{G}=50 \mu \mathrm{m}$.

early and advanced germ cells occurs, organs for transit and maturation of the spermatozoa seems to be normal. These results make to think that this pathological condition apparently not affects the fertility of this individual.
In molluscs, the prevalent condition of alterations in the reproductive system is the imposex, which produces a series of malformations in these animals, measurable at the macroscopic and cellular level, has been studied mostly in 
gastropods (Brick et al., 1996). At the cellular level, this condition involves damage to important organelles related to cellular metabolism, such as mitochondria, compromising the integrity of epithelium lining of the duct or seminal groove in the animal (Brick et al.). Our analysis to the optical microscope, indicates no histological alterations in epithelium lining of the seminal penile groove, and therefore discarding the possibility to be imposex. Sexual dimorphism of the gonad (orange, typical in male), and the histological analysis clearly showing the presence of the male germ cells, reinforces this idea; which rules out the possibility of a masculinized female by imposex. Similarly, this is the only case in the sample whit the morphological alteration, so it is unlikely that this pathology is produced by environmental agents. In the Caenogastropoda have been reported females affected by imposex diphallia (Meirelles et al.; Cardoso et $a l$.); however, in the case described here triphallia definitively is affecting a male individual.

Although the exact cause of the diphallia (a similar condition in mammals) is unknown, it has been postulated that in mammals it occurs during the first period of embryonic development when injury, chemical stress, or malfunctioning homeobox genes interfere with the function of the caudal cell mass of the fetal mesoderm at the time of the separation of the genital tubercle from the rectum in the urogenital sinus, to form the penis (Dominguez et al., 1993). On the other hand, in different species of mollusks have been reported a number of neuropeptides that act as morphogenetic factors of the penis and they are related to the reproductive behaviour of males (Oberdörster et al., 2005). Among these, the neuropeptide APGWamide is a neurotransmitter whose concentration is directly related to the eversion of the penis in gastropods and cephalopods (Koene et al., 2000; Morgan et al., 2002). This neuropeptide is secreted by the pedal ganglion in males and induces penile eversion and the formation of the deferent duct (Oberdörster et al.). It is possible that during the transcription of genes that activate the development of sexual organs, the set up of a transductional cascade involving neuromodulators, such as APGWamide, could alter the correct signaling, and consequently, producing morphological changes at the level of the reproductive system, that interferes with cellular processes involved in the morphogenesis of their structures, like the triphallia reported in this work.

\section{ACKNOWLEGMENTS}

This work was supported by the grant DIPUV 36/ 2004, Dirección de Investigación, Universidad de Valparaíso.

CASTILLO, V. M. \& BROWN, D. I. Un caso de Trifalia en el Caracol Marino Echinolittorina peruviana (Caenogastropoda: Littorinidae). Int. J. Morphol., 30(3):791-796, 2012.

RESUMEN: Los representantes gonocóricos de Littorinidae presentan un sistema reproductor organizado con órganos de tránsito que conectan al testículo con un pene especializado para la fecundación interna. Sin embargo, pueden ocurrir malformaciones a este nivel, como la trifalia (presencia de pene triple). Esta descripción corresponde a un caso de trifalia encontrado en el representante gonocórico Echinolittorina peruviana (Lamarck, 1822), habitante de las costas del Pacífico Sur. El análisis macro y microscópico revela que cada pene es un apéndice independiente cuya morfología individual es semejante a la de individuos normales, caracterizada por un pene de forma cónica no pigmentado asociado a una glándula de tipo mamiliforme ubicada en la base del tentáculo ocular derecho. El surco espermático cervical revestido por un epitelio simple cilíndrico ciliado y secretor, recorre el cuello del animal, se subdivide en la base de cada pene conformando el surco espermático peneano en cada uno de ellos, y asciende dorsalmente desde la base hasta el ápice. Los otros órganos que conforman el sistema reproductor poseen una organización normal (sin duplicaciones o triplicaciones), y el testículo organizado en acinos contiene todos los tipos celulares de la línea germinal masculina. Aunque aún la causa de esta patología es desconocida podría estar asociada a causas genéticas y no de tipo ambiental.

PALABRAS CLAVE: Molusco; Reproducción; Sistema reproductor; Morfología peneana; Malformación; Littorinidae.

\section{REFERENCES}

Brick, M.; Deutsch, U. \& Fioroni, P. Cellular effects of tributyltin (TBT) on the penis epithelium cells of prosobranchs (Hinia reticulata and Ocinebrina aciculata). Helgoland Mar. Res., 50(3):319-25, 1996.

Cardoso, R.; Caetano, C. \& Cabrini, T. Diphallia in imposexed females of marine gastropods: new record for Nassarius vibex from Brazil. Braz. J. Biol., 69(1):223-4, 2008.
Castillo, V. \& Brown, D. I. Microscopic anatomy of the male reproductive system in Echinolittorina peruviana (Mollusca: Caenogastropoda). Int. J. Morphol., 26(2):423-32, 2008.

Dardanelli, E.; Gómez, T.; Felipe, L.; Drajer, M. \& Moguillansky, S. Síndrome de duplicación caudal. Rev. Argent. Radiol., 69(2):121-4, 2005. 
Dominguez, R.; Rott, J.; Castillo, M.; Pittaluga, R. R. \& Corriere, J. N. Jr. Caudal duplication syndrome. Am. J. Dis. Child., 147(10):1048-52, 1993.

Gabe, M. Techniques Histologiques. Paris, Masson et Cie Editeurs, 1968.

Koene, J. M.; Jansen, R. F.; Ter Maat, A. \& Chase, R. A conserved location for the central nervous system control of mating behavior in gastropod molluscs: Evidence from a terrestrial snail. J. Exp. Biol. 203(PT 6):1071-80, 2000.

Loynachan, A. T.; Jackson, C. B. \& Harrison, L. R. Complete diphallia, imperforate ani (type 2 atresia ani), and an accessory scrotum in a 5-day-old calf. J. Vet. Diagn. Invest., 18(4):40812,2006

Meirelles, C. A. O.; Castro, I. B. \& Pinheiro, J. C. L. A first record of biphallia in imposexed female of Leucozonia nassa (Caenogastropoda: Fasciolariidae). J. Mar. Biol. Ass. U. K. 2 Biodiv. Rec., 5424:1-3, 2007.

Morgan, P. T.; Jing, J.; Vilim, F. S. \& Weiss, K. R. Interneuronal and peptidergic control of motor pattern switching in Aplysia. J. Neurophysiol., 87(1):49-61, 2002.

Oberdörster, E.; Romano, J. \& McClellan-Green, P. The neuropeptide APGWamide as a penis morphogenetic factor (PMF) in gastropod mollusks. Integr. Comp. Biol., 45(1):28$32,2005$.

Pantín, C. Técnicas Microscópicas para Zoólogos. León, España, Editorial Academia, 1967.

Sharma, K.; Jain, R.; Jain, S. K. \& Purohit, A. Concealed diphallus: a case report and review of the literature. J. Indian Assoc. Pediatr. Surg., 5(1):18-21, 2000.

Valderrama, K.; Oliva, M.; Campos, B. \& Brown, D. Parasitic castration of Eurhomalea lenticularis (Bivalvia:Veneridae) by a digenetic trematode: Quantitative histological analysis. Dis. Aquat. Organ., 59(2):151-8, 2004.
Correspondence to:

Donald I. Brown

Laboratorio de Biología de la Reproducción y del Desarrollo

Departamento de Biología y Ciencias Ambientales

Facultad de Ciencias

Universidad de Valparaíso

Casilla 5030, Valparaíso

CHILE

Phone number: 56-32-2508035

Fax number: 56-32-2508042

Email: donald.brown@uv.cl

Received: 04-06-2012

Accepted: 07-07-2012 